\title{
脳卒中片麻痺患者の体幹筋力の左右差には 股関節周囲筋の麻瘏が影響する
}

\author{
Paralysis of Hip Joint Muscles Causes Lateral Differences \\ in Trunk Muscle Strength of Hemiplegic Stroke Patients
}

\author{
海野 光信 ${ }^{1)}$ 村上 忠洋 ${ }^{2)}$ 畑迫 茂樹 ${ }^{2}$ 佐々木 友也 ${ }^{3)}$ 千邑 彰人 ${ }^{4)}$ \\ Mitsunobu UNNO ${ }^{1)}$, TADAhiro MURAKAMI ${ }^{2)}$, ShigeKi HATASAKO ${ }^{2)}$, TOMONARI SASAKI ${ }^{3)}$, AKIHITo CHIMURA ${ }^{4)}$ \\ 1) Department of Rehabilitation, Ukai Hospital: 30 Kotobuki-cho, Nakamura-ku, Nagoya-shi, Aichi 453-0028, Japan. TEL+81 \\ 52-461-3131 E-mail: unno.mitsunobu@sepia.plala.or.jp \\ ${ }^{2)}$ Chubu Rehabilitation College \\ ${ }^{3)}$ Department of Rehabilitation, Sendai Rehabilitation Hospital \\ ${ }^{4)}$ Department of Rehabilitation, Shiroyama Hospital
}

Rigakuryoho Kagaku 30(3): 449-452, 2015. Submitted Dec. 15, 2014. Accepted Feb. 7, 2015.

\begin{abstract}
Purpose] To clarify whether or not paralysis of the hip joint muscles causes lateral differences in the lateral trunk flexion strength hemiplegic stroke patients. [Subjects and Methods] The subjects were 9 first-time hemiplegic stroke patients. In a sitting on the edge of the bed position, with and without pelvis fixation, the muscle strengths of isometric trunk flexion to the paretic and non-paretic sides were measured and compared. [Results] Without pelvis fixation, the paretic side muscle strength was significantly lower than that of the non-paretic side, and this tendency was especially strong in subjects with more severe hip joint muscle paralysis. There was no significant difference between paretic and non-paretic sides with pelvis fixation. [Conclusion] In hemiplegic stroke patients, lateral differences appear in trunk muscle strength due to paralysis of the hip joint muscles, which work to stabilize the pelvis, but when the pelvis is passively fixed, this lateral difference disappears due to the minimization of their influence.
\end{abstract}

Key words: stroke, trunk muscle strength, laterality

要旨：〔目的〕脳卒中片麻瘏患者における体幹側屈筋力の左右差に股関節周囲筋の麻痺が影響するか否かを明らかに する。【対象と方法〕初発脳卒中片麻痺患者 9 名を対象に, 端座位で麻痺側と非麻痺側方向への等尺性体幹側屈筋力 を「骨盤固定なし」と「骨盤固定あり」で測定し，麻痺側と非麻痺側で比較した。〔結果〕「骨盤固定なし」では麻痺 側筋力が非麻痺側筋力に比べ有意に低下し, 股関節周囲筋の麻痺が重度な者ほどその傾向が強かった。骨盤固定あり」 では左右差はみられなかった。〔結語〕脳卒中片麻疩患者における体幹筋力の左右差は骨盤の固定に働く股関節周囲 筋の麻痺の影響により出現し，骨盤を他動的に固定しこの影響を小さくすることで左右差がなくなると考える. キーワード : 脳卒中片麻痺患者, 体幹筋力, 左右差

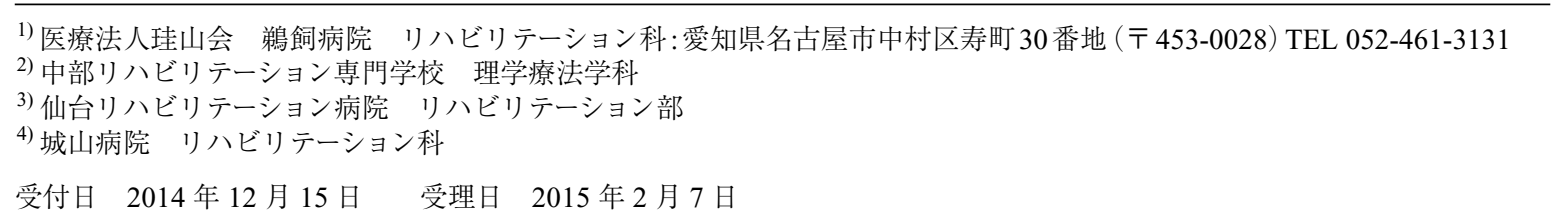




\section{I. はじめに}

脳卒中片麻痺患者における体幹の運動機能障害は, 麻 痺側上下肢の運動機能障害や半側空間無視などとともに 日常生活活動を阻害する重要な因子であり ${ }^{1,2)}$, その機 能改善を図るための治療手段も注目されている 3-5).

Bohannon $\left.{ }^{6}\right)$ は, 脳障害患者における体幹の運動機能 として座位での体幹側屈筋力を測定し, 麻痺側の体幹側 屈筋力は非麻痺側と比べ $32.1 \%$ 減少しており, 四肢と 同様に体幹筋においても脳障害によって片側性に機能障 害がみられたと報告している。しかし，体幹筋は左右両 側の大脳皮質および脳幹から両側性神経支配 7-11) を受 け，脳卒中などにより一側の大脳半球が障害されても， 反対側からの神経支配は残存しているため, 運動麻疩に よる機能の左右差は生じ難いはずである。したがって, Bohannon ${ }^{6)}$ の報告にみられる座位での麻痺側体幹筋の 筋力低下は，体幹筋自体の麻痺によって生じるのではな く, 股関節周囲筋の麻痺によって体幹運動の土台となる 骨盤の固定性が低下するため, 間接的に麻痺側体幹側屈 筋力を発揮できない状態にあると考えた。

そこで我々は，このような体幹筋力の左右差は，骨盤 を固定することで消失し，その骨盤の固定性に影響する 股関節周囲筋の麻痺が重度な者ほど大きくなると仮説を たてた．今回の研究の目的はこの仮説を検証することで, 脳卒中片麻痺患者における体幹側屈筋力の左右差に股関 節周囲筋の麻瘏が影響するかを明らかにすることである.

\section{II. 対象と方法}

対象は当法人の回復期リハビリテーション病棟に入院 していた初発脳卒中片麻瘏患者で，端座位保持が自己に て可能であった 9 名とした. 疾患の内訳は脳出血 3 名, 脳梗塞 6 名, 麻痺側 は右 5 名, 左 4 名, 下肢 Brunnstrom recovery stage（以下, BRS）は IV-4 名, V-2 名, VI-3 名, 発症からの期間は平均で $78.3 \pm 35.2$ 日であった (表 1). 対象から除外した者は, 脳卒中に よる病巣が大脳半球以外に存在する者, 肩関節や腰部に 疼痛があり測定が困難な者, 上腕近位部や脊椎, 股関節
部に既往症がある者，麻痺側上肢の筋緊張が高くなり， 麻痺側の体幹側屈筋力の測定が困難な者とした。なお対 象者には研究の目的, 測定方法, データの取り扱いにつ いて口頭で説明し，研究に参加することの同意を得た.

対象者の体幹側屈筋力と麻痺側における股関節部の運 動麻痺の程度は以下の方法で測定した。体幹側屈筋力の 測定は徒手筋力計（ANIMA 社製 $\mu$-Tas F1）を用い, Bohannon 6)の方法を参考に行った，測定肢位は足底非 接地で体幹を直立させた端座位とし, 両上肢は体幹前方 で組ませ，上肢が体から離れ肩外転運動が起こらないよ う事前に説明し注意させた。 その肢位で対象者の肩峰直 下の上腕近位部に筋力計の圧センサーをあて, 麻疩側お よび非麻痺側方向へ体幹側屈を行わせ，等尺性最大筋力 を測定した。その際，Bohannon6)の方法に準じ骨盤を 固定せず，大腿部のみを検査者の徒手とベルトで治療台 に押し付け固定する条件（以下，「骨盤固定なし」）と， 上記の大腿部の固定とともに，もう一人の検査者が徒手 で骨盤を後方から治療台に押し付け固定する条件（以下， 「骨盤固定あり」）の 2 条件で測定を行った。体幹側屈筋 力は「骨盤固定なし」，「骨盤固定あり」の順に，いずれ の条件においても非麻瘏側から測定し, その後麻痺側の 順で行った。測定開始前に体幹前後屈, 回旋運動が生じ ないようにすること, 上肢を外転して代償させないこと を説明し, 練習を行った後, 両条件で麻痺側, 非麻痺側 方向ともに 3 回ずつ測定した。 2 条件における麻痺側と 非麻痺側の測定結果はそれぞれ平均值を算出し代表值 （kgf）とした。 また体幹側屈筋力の左右差の程度を示す ため, 麻疩側筋力を非麻痺側筋力で除し, 麻疩側筋力比 を求めた．筋力測定は筋力計圧センサーの押し当て，大 腿部の固定, 骨盤の固定をそれぞれ同一検査者が行っ た．検査者は測定中に対象者が誤った体幹運動や上肢の 外転運動による代償動作の出現を目視にて確認し, これ らの現象を認めれば再測定した。

なお予備実験として体幹側屈筋力の測定方法の信頼性 を検討した，対象は今回の研究対象とは異なる 8 名の脳 卒中片麻瘏患者とし, 同一検査者が 1 週間以内の 2 日間 で測定した結果の級内相関係数 $(1,1)$ を求めた。「骨 盤固定なし」における麻瘏側筋力の級内相関係数は 0.93

表 1 対象者の基本属性情報

\begin{tabular}{|c|c|}
\hline 年＼cjkstart齢 $($ 歳)* & $74.1 \pm 5.1$ \\
\hline 性＼cjkstart別（名） & 男性：6 女性：3 \\
\hline 身 長 $(\mathrm{cm}) *$ & $158.8 \pm 6.5$ \\
\hline 体 重 $(\mathrm{kg}) *$ & $56.6 \pm 5.6$ \\
\hline 病＼cjkstart型（名） & 脳出血：3 脳梗塞 : 6 \\
\hline 麻痺側（名） & 右: 5 左 4 \\
\hline 下肢 Brunnstrom Recovery Stage（名） & IV $: 4 \quad$ V : $2 \quad$ VI $: 3$ \\
\hline 発症からの期間（日）* & $78.3 \pm 35.2$ \\
\hline
\end{tabular}

*の数值は平均值 \pm 標準偏差を示す，それ以外は分布度数を示す. 
(95\%信頼区間：0.70-0.98)，非麻疩側筋力では 0.96 (0.82-0.99), 「骨盤固定あり」における麻瘏側筋力は $0.94(0.76-0.99)$, 非麻痺側筋力では $0.92(0.69-0.98)$ と, いずれも高い信頼性を示した。

股関節部の運動麻痺の評価には Stroke Impairment Assessment Set（以下, SIAS）の下肢近位テストを用い, 股屈曲得点を 0 〜 点で判定した ${ }^{12)}$.

統計手法として「骨盤固定なし」および「骨盤固定あ り」における麻痺側と非麻痺側との体幹側屈筋力の比較 には，Wilcoxonの符号付順位和検定を用いた。また SIAS 股屈曲得点と「骨盤固定なし」および「骨盤固定 あり」における体幹側屈筋力の麻疩側筋力比との相関関 係については, Spearmanの順位相関係数 $(\rho)$ を用い 検討した。なお，これらの統計解析にはSPSS 社製 Dr.SPSS II for Windows（11.0.1.J）を用い，有意水準を $5 \%$ とした.

\section{III. 結 果}

「骨盤固定なし」および「骨盤固定あり」における麻 痺側と非麻痺側の体幹側屈筋力の結果を表 2 に示す. 「骨盤固定なし」では, 麻痺側筋力が非麻痺筋力に比べ 有意に低下していたが，「骨盤固定あり」においては麻 痺側と非麻痺側で有意な差はみられなかった。

SIAS 股屈曲得点は中央值 4 点であり, 最小值 2 点, 最大值は 5 点であった。各条件における麻痺側筋力比の 結果，および SIAS 股屈曲得点との相関を表 3 に示す. 麻痺側筋力比と SIAS 股屈曲得点との相関は, 「骨盤固 定なし」では有意な相関を認めたが,「骨盤固定あり」 においては有意な相関を認めなかった。

\section{IV. 考 察}

今回測定した体幹側屈筋力の結果では,「骨盤固定な
し」において有意な左右差が，さらにこの左右差の程度 と麻瘏側の股関節周囲筋の運動障害の程度 (SIAS 股屈 曲得点）に有意な相関を認めた。これらのことから「骨 盤固定なし」における体幹側屈筋力は麻痺側の股関節周 囲筋の麻痺の影響を受け, 左右差が生じていたと考え る.

Bohannon ${ }^{6)}$ の方法に準じた「骨盤固定なし」の条件 では, ベルトや徒手にて大腿部を固定しているものの, 体幹筋の付着部である骨盤は固定していない.したがっ て座位で等尺性の体幹側屈筋力を発揮しょうとすると, 体幹側屈筋の収縮に伴い, 体幹側屈運動ではなく, 側屈 側の骨盤が引き上げられ，骨盤は前額面上で回転してし まう。このため十分な等尺性体幹側屈筋力を発揮させる ためには，この動きを抑えるために股関節周囲筋による 骨盤の固定が必要となる。

一方「骨盤固定あり」の条件では，検査者が直接的に 骨盤をより強固に固定することで，股関節周囲筋による 骨盤の固定の必要がなくなった。これにより下肢の影響 を除いた体幹側屈筋力の測定が可能となり, 左右差が生 じなかったと考える。CT 像を用いて体幹筋の筋断面積 を麻痺側と非麻痺側で比較した小竹ら 13)，鈴木ら 14)の 報告において，体幹筋の筋断面積に左右差が認められな かったことからも，脳卒中片麻疩患者の体幹笳力には見 かけ上の左右差が存在し，その左右差は麻痺側の股関節 周囲筋の麻痺による骨盤の固定性が影響して生じている が, 本来の体幹筋が発揮できる筋力には差がないといえ る.

本研究では, 回復期リハビリテーション病棟に入院し ていた初発脳卒中片麻瘏患者で, 下肢の運動麻痺が中等 度から軽度の症例を対象としており，骨盤の固定性がよ り悪化していると思われる重度の運動麻痺を呈した症例 を含めていない。これは下肢 BRS が I 〜 III の重度から 中等度の運動麻瘏を呈した症例では, 端座位保持に介助 または監視が必要であり，かつ麻痺側上肢に亜脱臼や肩

表 2 体幹側屈筋力值

\begin{tabular}{ccc}
\hline & 麻痺側 & 非麻痺側 \\
\hline 骨盤固定なし & $6.8(3.3 \sim 13.7)$ & $8.9(7.1 \sim 16.9) *$ \\
骨盤固定あり & $7.3(4.7 \sim 14.3)$ & $8.5(5.5 \sim 15.2)$ \\
\hline 数值は中央值 (最小〜最大) $)$ を示す (単位 $: \mathrm{kgf}), *: \mathrm{p}<0.05$.
\end{tabular}

表 3 各条件における麻瘏側筋力比の結果およびSIAS 股屈曲得点との相関

\begin{tabular}{|c|c|c|}
\hline & 「骨盤固定なし」 & 「骨盤固定あり」 \\
\hline 麻痺側筋力比（麻痺側／非麻痺側） & $0.81(0.39 \sim 1.10)$ & $0.94(0.56 \sim 1.25)$ \\
\hline SIAS 股屈曲得点との相関関係 & $\rho=0.84 * *$ & $\rho=0.46$ \\
\hline
\end{tabular}


手症候群などによる肩関節痛を有している者が多く，今 回の測定方法では体幹筋力の測定が困難であったため対 象から除外されていた，よって今回の研究では重度から 中等度の運動麻痺を呈する症例を含めた体幹側屈筋の機 能障害を把握することは困難である。しかし前述の鈴木 ら ${ }^{14)}$ の報告では, 対象である 80 名の脳血管障害患者の なかで, 上下肢の運動麻痺が BRS I 〜 III の者が 7 割以 上存在し, このうち約 8 割は傍脊柱筋の筋断面積に左右 差が認められなかったことから, 運動麻疩が重度な症例 に打いても体幹筋の機能の左右差は生じ難いことが予想 される。

脳卒中片麻痺患者の体幹機能を評価する方法 15-17) は これまでにいくつか報告されているが，その多くが座位 での運動機能や動作能力を評価するものであり，今回の 研究に扔ける「骨盤固定なし」条件のように, 骨盤の固 定性に影響する下肢の運動機能を完全に排除することは 困難である。 そのため臨床場面において体幹機能を評価 する際は, その結果に下肢の運動機能が影響しているこ とを念頭に置いて解採する必要がある.

\section{引用文献}

1) 藤原俊之: 脳卒中の体幹機能の評価と予後. 臨床リ八, 2002, 11(10): 942-946.

2) 江連覀弥, 原田慎一, 小澤佑介 - 他 : 脳卒中片麻痺者の体 幹機能と日常生活活動 (ADL) との関係について. 理学療法 科学, 2010, 25(1): 147-150.

3) デービス PM : Right in the Middle（成人片麻瘒の選択的な 体幹活動)。冨田昌夫 (監訳)，シュプリンガー・フェアラー ク東京, 東京, 2005

4) 大㭇利夫 : ボバースアプローチ, 現在そして将来にわたり 発展しつづける概念と治療実践 その2一神経リハビリ テーションの担い手として一. 理学療法学, 2010, 37(3):
178-180.

5) 佐藤房郎：中枢神経疾患の理学療法とコアスタビリティト レーニング．理学療法, 2009, 26(10): 1219-1227.

6) Bohannon RW: Lateral trunk flexion strength: impairment, measurement reliability and implications following unilateral brain lesion. Int J Rehabil Res, 1992, 15(3): 249-251.

7) Duus P : 神経局在診断 その解剖, 生理, 臨床 改訂第 4 版. 半田 肇(監訳), 文光堂, 東京, $2005, \mathrm{p} 40$.

8) 太田富雄, 西村周郎: 脳神経外科学 改訂第3 版. 金芳堂, 京都, 1981, pp60-64.

9) Plassman BL, Gandevia SC: Comparison of human motor cortical projections to abdominal muscles and intrinsic muscles of the hand. Exp Brain Res, 1989, 78(2): 301-308.

10) 中馬孝容, 眞野行生, 高桝哲也 : 神経内科領域における磁 気刺激法の臨床応用。臨床脳波, 1996, 38(1): 1-5.

11) 北村純一：脳卒中片麻痺の運動障害とその回復. 総合リ八 1996, 24(11): 1063-1067.

12) 道免和久: 脳卒中片麻痺患者の機能評価法 Stroke Impairment Assessment Set (SIAS) の信頼性および妥当性の 検討 (1) 一麻痺側運動機能, 筋緊張, 腱反射, 健側機能一. リ八医学, 1995, 32(2): 113-122.

13) 小竹伴照, 土肥信之：CT像による脳血管障害片麻痺患 者の体幹掞よび下肢筋の検討. リ八医学, 1991，28(8): 607-612.

14) 鈴木美保, 園田 茂, 才藤栄一・他：CT 用いた傍脊柱 筋測定一片麻瘏患者における左右差の検討一. リ八医学, 1996, 33(3): 176-181.

15) 千野直一, 椿原彰夫, 園田茂・他：脳卒中の機能評価 SIAS と FIM (基礎編)。金原出版，東京，2012，pp60-62.

16) Verheyden G, Nieuwboer A, Mertin J, et al.: The Trunk Impairment Scale: a new tool to measure motor impairment of the trunk after stroke. Clin Rehabil, 2004, 18(3): 326-334.

17) 奥田 裕, 荻野禎子, 小澤佑介-他：臨床的体幹機能検 査（FACT）の開発と信頼性. 理学療法科学, 2006, 21(4): 357-362. 